\title{
Characteristics, Comorbidities, and Outcomes Among Patients Admitted With COVID-19 in Sheikh Khalifa Medical City: A Retrospective Study
}

Moustafa Abdelwahab ( $\sim$ moustafawahab@hotmail.com )

Shaikh Khalifa Medical City

Lara Al Qadi

Shaikh Khalifa Medical City

Mohammad Al Jawabreh

Shaikh Khalifa Medical City

Hanan Sulaiman

Shaikh Khalifa Medical City

Mariam Al Blooki

Shaikh Khalifa Medical City

\section{Research Article}

Keywords: COVID-19, Coronavirus, UAE , Clinical characteristics, Outbreak

Posted Date: March 19th, 2021

DOI: https://doi.org/10.21203/rs.3.rs-153450/v2

License: (9) This work is licensed under a Creative Commons Attribution 4.0 International License.

Read Full License 


\section{Abstract}

Background: Many studies were published to describe the clinical characteristics of COVID-19, however there is still lack of knowledge and it's time to take stock of the war against coronavirus disease 2019 (COVID-19) pandemic before we hit another million in a matter of days. Simply Identifying COVID-19 features will help in mapping the disease and guiding pandemic management. A retrospective review, retrospective study was initiated in SKMC to describe the demographic data, clinical characteristics, and outcomes of COVID-19 cases who were hospitalized during that period.

Methods: Confirmed positive COVID-19 sample patients from April $1^{\text {st }} 2020$ to May $31^{\text {st }} 2020$ in Sheikh Khalifa Medical City. Clinical characteristics, Demographic data, incubation periods, laboratory findings, and patient outcomes data retrieved from 336 cases in the electronic medical chart (SALAMTAK).

Results: The median age was 44 years and $83.9 \%(n=282)$ of the patients were men. The patients with diabetes mellitus being the most common risk factor (25.0\%), followed by hypertension (22.9\%) and Age $\geq 60$ were $(13.4 \%)$. Total 36 patients $(10.7 \%)$ were asymptomatic. The most common symptoms were upper respiratory tract symptoms, manifested as dry cough (70.2\%), and followed by fever (54.2\%), shortness of breath $(43.5 \%)$, headache $(25.9 \%)$ and sore throat $(25.3 \%)$. Less common symptoms were diarrhea (16.7\%) chest pain (14.6\%). The maximum length of stay is 32 days. The minimum length of stay in [ICU/HDU] was 1 day and the maximum was 21 days.

Conclusion: In this retrospective study, fever and cough were common symptoms. Special attention should be given to patients with risk factors especially patients with one risk factor such as diabetic patients, patients with hypertension and older patients over 60 years as they are the most highly prevalent in this case series. Disease was affecting males and D-dimer was significantly elevated in deceased patients.

\section{Introduction}

Coronavirus disease 2019 (COVID-19) outbreak has created a global health crisis that has had a deep impact on our healthcare system. In December 2019, China reported to the World Health Organization (WHO) multiple cases of unexplained lower respiratory tract infections with mortality rate of $2.3 \%{ }^{(1-3)}$. A coronavirus that genetically related to the SARS virus was identified (SARS-CoV-2). This new viral syndrome named by the WHO as coronavirus disease 2019 (COVID-19).

The first confirmed case in the United Arab Emirates announced on 29 January 2020. It was the first country in the Middle East to report a confirmed case. The first patient, a 73-year-old Chinese woman, released on 9 February after recovering.

Many retrospective cohort studies done worldwide with limited Information available to describe the presenting characteristics, treatment and outcomes of patients requiring hospitalization with COVID-19. However, there are significant differences from country to another in population demographics, 
prevalence of comorbidities, readmissions and outcomes. There are two key factors to determine if signs and symptoms of any patient is compatible to COVID-19 which are case definition and clinical judgment and if confirmed, patient should be tested and isolated.

The most common signs and symptoms include fever, fatigue, cough, headache, and sore throat $(4,5,9)$ as not many COVID-19 cases develop vital signs abnormalities. Symptoms were reports four to five days after exposure while the incubation period is thought to be within 14 days as mentioned in many studies $(4,7)$ with Special attention to be addressed to asymptomatic carriers and workers in health care facilities as they play key role in disease transmission ${ }^{(9)}$.

There is variability of the disease which depends on many factors such as distinct demographic features, comorbidities, and immune system responses among different populations. The most common manifestation is Pneumonia that can progress to Acute Respiratory Distress Syndrome (ARDS) ${ }^{(7)}$. Many serious complications were reported, such as septic shock, arrhythmias and multi-organ failure $(8,9)$.

Health organizations constantly issue advices and guidelines to best mitigate the impact of the crisis. At the same time, scientists around the world work hard and information about the transmission mechanisms, the clinical spectrum of disease, new diagnostics, and prevention and therapeutic strategies are rapidly developing. SKMC has developed internal protocols and guidelines that updated regularly.

This study describes all demographic, signs and symptoms, risk factors, clinical tests result and outcome for hospitalized patients with COVID-19 in SKMC Abu Dhabi during the first period. The aim of this study is to identify patient characteristics with COVID-19 and the comorbidity condition.

\section{Methods}

The study conducted at SKMC (Sheikh Khalifa Medical City) in Abu Dhabi, the largest academic tertiary hospital in Abu Dhabi, united Arab of emirates. All consecutive adult patients $\geq 18$ years of age who were admitted to SKMC from April 1st to May 31st where included.

A total population of 2630 patients identified who had the coding of COVID-19 as principle diagnosis coding. Sample size calculated with confidence level $95 \%$ and margin of error $5 \%$, therefore the final sample size was 336 patients. A randomized sample of 336 patients obtained, from different hospital wards including nation hospital that run by SKMC team, ICU and HDU. Patients considered to have confirmed infection if the initial test result was positive or if it was negative but repeat testing was positive.

All data was obtained from electronic patients records (SALAMTAK), and all analyses were performed using IBM SPSS software package version 20.0. (Armonk, NY: IBM Corp). The Kolmogorov-Smirnov test was used to verify the normality of distribution of variables. Comparisons between groups for categorical variables were assessed using Chi-square test (Monte Carlo). Kruskal Wallis test was used to compare different groups for not normally distributed quantitative variables. 
All measures taken to preserve the integrity and privacy of data. All subjects assigned a study identification number. The electronic database secured with passwords and access was limited to selected investigators. This study approved by IRB research and ethical committee in Department of Health - Abu Dhabi (Approval number DOH/CVDC/2020/1517). All methods carried out in accordance with relevant guidelines and regulations.

No need for patient Consent. IRB research and ethical committee in Department of Health - Abu Dhabi committee waived it as data collected from electronic medical record with hiding patient personal details.

Patient Demographic, risk factors, symptoms, laboratory, and outcome data of COVID-19 patients obtained. COVID-19 diagnosed based on the results of quantitative RT-PCR testing, of nasopharyngeal samples in accordance with the protocol established by the World Health Organization ${ }^{(10)}$. Then, data independently entered into electronic sheets by four data collectors and any discrepancies resolved by the primary investigator on the verification report on the records.

A total of 10 patient risk factors (comorbidities) were included while patient symptoms included 7 symptoms. For the care related data, patient level was classified into 3 categories as per SKMC protocol which is integrated from DOH (Department of Health) national protocol. This classification was into 3 levels, level A: The patient was asymptomatic OR mild symptoms with radiological evidence of pneumonia (Mild), Level B: The patient was Asymptomatic with radiological evidence or pneumonia OR mild URTI with risk factors (Moderate) and Level C: The patient was critically ill and admitted to ICU.

D-Dimer level was classified into two groups, $>1$ OR $<1$, while the QTc measurement were taken for ECG done upon admission. Laboratory testing defined as the first test results available, typically within 24 hours of admission. Patient discharge were classified into 3 groups: quarantine, discharge to health care facility and deceased patients. Quarantine included discharge to home, hotel or Camps.

In our Descriptive statistics, we used to describe the demographic baseline data and clinical characteristics. Categorical variables presented as counts and percentages, whereas continuous variables presented as means and standard deviations when data were normal or as medians (MDs) and interquartile ranges (IQRs) otherwise. The t-test used for continuous variables and chi-squared test used for categorical variables. A p-value of $<0.05$ was considered statistically significant.

\section{Results}

Total number of 336 patients were included in the study. The majority were males 282 patients (83.9\%), females 54 patients (16.1\%) with median age was 44 years (IQR 36-54.5). National (Emirati) were 21 patients (6.3\%) and Non-National 315 patients (93.8\%). 31 patients (9.2\%) were aged 18-29, 186 patients $(55.4 \%)$ were aged $30-49,80$ patients $(23.8 \%)$ were aged $50-60$ and 39 patients $(11.6 \%)$ were aged $>60$. The minimum age was 19 years and 89 years was the maximum age. 
Patient who had Risk factors (comorbidities) were $87.8 \%$ of the patients with diabetes mellitus being the most common risk factor (25.0\%), followed by hypertension (22.9\%) and Age $\geq 60$ were $(13.4 \%)$ (Table 1).

Patients were classified according to signs and symptoms into three levels, level A for patients were Asymptomatic OR mild symptoms with radiological evidence of pneumonia (Mild), Level B for patients who were Asymptomatic with radiological evidence of pneumonia OR mild URTI with risk factors (Moderate) while level $\mathrm{C}$ was for critically ail patients.

For level A patients, 75 patients (70.1\%) were males compared to 32 females (29.9\%). For patient level B, 194 patients $(90.2 \%)$ were males compared to 21 patients females (9.8\%). For patients level C, 13 patients $(92.9 \%)$ were males compared to 1 female patient $(7.1 \%)$ (Table 2$)$.

Patients aged between 18-29 years were 16 patients (15\%) in level A, 15 patients ( $7 \%$ ) in level $B$ and 0 patient ( $0 \%)$ in level C. Patients aged between $30-49$ years were $56(52.3 \%)$ in level A, $124(57.7 \%)$ in level $B$ and 6 (42.9\%). Patients aged between 50-60 years were $17(15.9 \%)$ in level A, 58 (27\%) in level B and 5 (35.7\%) in level C. Patient age > 60 were $18(16.8 \%)$ in level A, 18 (8.4\%) in level B and $3(21.4 \%)$ in level C (Table 2).So gender male was significantly in level $B$ with $p=0.109$

Total 36 patients (10.7\%) were asymptomatic. The most common presenting symptoms in the symptomatic patients were upper respiratory tract symptoms, manifested as dry cough (70.2\%), and followed by fever $(54.2 \%)$, shortness of breath (43.5\%), headache $(25.9 \%)$ and sore throat $(25.3 \%)$. Less common symptoms were diarrhea $(16.7 \%)$ chest pain (14.6\%). (85.5\%) patients were with QTc result on ECG $<430,(10 \%)$ patients were $430-450$ and $(4.5 \%)$ patients were $>450$ (table 3 ). D-dimer results $<1$ $\mathrm{mcg} / \mathrm{mL}$ were $(49.4 \%)$ and $(17.3 \%)$ were $>1 \mathrm{mcg} / \mathrm{mL}$ (Table 3).

The minimum length of stay is 1 day and the maximum is 32 days. The mean length of stay was $5 \pm 4.8$ days and the median (IQR) 3 (2-6) (Table 3). The minimum length of stay in [ICU/HDU] was 1 day and the maximum was 21 days. The Mean length of stay in [ICU/HDU] $6.3 \pm 5.8$ and the median (IQR) was 4 (1-9) (table 3).

Patients aged between 30-49 with no risk factors were $124(66.7 \%)$ followed by patients aged between 30-49 45 (24.2\%) with only 1 risk factor (table 4). Patient with mild symptoms were 15 (48.4\%) aged between $18-29,85$ patients $(45.7 \%)$ aged between $30-49,28$ patients $(35 \%)$ aged between $50-60$ and 15 patients $(38.5 \%)$ aged $>60$. Patients with moderate/severe symptoms were $11(35.5 \%)$ aged between $18-29,86$ patients (46.2\%) aged between $30-49,43$ patients (53.7\%) aged between $50-60$ and 17 patients $(43.6 \%)$ aged $>60$ (table 4 ).

Among 336 patients who were discharged or had deceased at the study end, total number of patients who died is 12 patients with mortality rate is (3.5\%). 10 patients of them male (83.3\%) while $91.7 \%$ were non-national. 
The readmission rate within 14 days of discharge was $4.7 \%$ with total number of 16 patients, 15 patients of them is non-national (93.7\%)

For both patients discharged alive and those who died it was noticed that half of the deceased patients (50\%) were aged $30-49$ and 5 patients of them in that age is male with (83.3\%).

Total number of 16 patients were readmitted to the hospital within 14 days of discharge with 10 patients males (62.5\%) and 6 patients females (37.5\%). 7 patients (43.7\%) with age of $30-49$ were readmitted within 14 days of discharge.

Average length of stay for discharge patients was 4.8 days while for deceased patients was 10.2 days. 53 patients $(28.4 \%)$ of the age of 30-49 used oxygen therapy and $86.8 \%$ were on nasal cannula.

16 patients had unplanned readmission (table 5). Patients who had ECG done on admission were (98.3\%) (Table 6). Majority of patients discharged to Quarantine (table 7).

The highest risk factor in deceased patients was diabetes mellitus (58.3\%) (Table 5).

\section{Discussion}

This is the first comprehensive study to our knowledge with details such as clinical, demographic features, laboratory, cardiology aspects and outcome represents series of sequentially inpatients with confirmed COVID-19 in Abu Dhabi, United Araba of Emirates.

Males were relatively higher than females as many previous studies $(11,12,13)$ while the majority of the patients were young in the middle of age. Most of the cases were male asymptomatic patients with radiological evidence of pneumonia or mild upper respiratory tract infection with risk factors (Moderate). Diabetic patients, patients with hypertension, males and older persons were highly prevalent in this case series and the pattern was similar to data reported from China. ${ }^{(13)}$

For all discharged patients, the median incubation period was 6 days, which is close to reported incubation periods reports of this pandemic. ${ }^{(14)}$ Furthermore, $19 \%$ received ICU/HDU care while the international estimate percentages for ICU care only is $4.7 \%{ }^{(5)}$

The findings of mortality rates for ventilated patients are similar to smaller case series reports of critically ill patients in the US. ${ }^{(15)}$ Our study shows that $11.6 \%$ of the patients were above 60 years old which is almost similar to what has been described in Jorden ${ }^{(16)}$ but lower than what has been described in Asia and Europe ${ }^{(17-21)}$

In addition, mortality rates in this case series were significantly higher, possibly due to differences in thresholds for hospitalization. 
Mortality rates reported in this study only for patients with definite outcomes (discharge or death), and longer-term study may find different mortality rates as different segments of the population are infected.

$4.7 \%$ of COVID-19 patients readmitted within 14 days of discharge and further analysis and investigation done for both related and unrelated readmission.

This study has several limitations. First, the study population only included inpatients within the Sheikh Khalifa Medical City. Second, the sample size was 336 patients. Third, the data were collected manually from the electronic health record database, as there was no automated report for these patients

\section{Conclusions}

Few months after the COVID-19 infections, cough and fever were the most common clinical symptoms; however, most of the cases were in the middle age.

Special attention should be given to patients with risk factors especially patients with one risk factor such as diabetic patients, patients with hypertension and older patients over 60 years as they are most highly prevalent in this case series. Disease was affecting males and D-dimer was significantly elevated in deceased patients.

\section{References}

1. Li, X. Guan, P. Wu, et al., Early transmission dynamics in Wuhan, China, of novel coronavirus-infected pneumonia, N. Engl. J. Med. (2020) published online Jan 29.

2. Liu, A.A. Gayle, A. Wilder-Smith, J. Rocklov, The reproductive number of COVID-19 is higher compared to SARS coronavirus, J. Trav. Med. (2020) published online Feb 13.

3. Novel Coronavirus Pneumonia Emergency Response Epidemiology Team, The epidemiological characteristics of an outbreak of 2019 novel coronavirus diseases (COVID-19) in China, Zhonghua Liuxingbingxue Zazhi 41 (2) (2020 Feb 17)145-151, https://doi.org/10.3760/cma.j.issn.02546450.2020.02.003.

4. Guan W, Ni Z, Hu Y, Liang W, Ou C, He J, et al. Clinical characteristics of Corona-virus Disease 2019 in China. New Engl J Med 2020, http://dx.doi.org/10.1056/NEJMoa2002032.

5. Jiang F, Deng L, Zhang L, Cai Y, Cheung C, Xia Z. Review of the clinical characteristics of Coronavirus Disease 2019 (COVID-19). J Gen Intern Med 2020, http://dx.doi.org/10.1007/s11606-020-05762-w.

6. Chan J, Yuan S, Kok K, To K, Chu H, Yang J, et al. A familial cluster of pneumonia associated with the 2019 novel coronavirus indicating person-to-person trans-mission: a study of a family cluster. Lancet 2020;395(10223):514-23, http://dx.doi.org/10.1016/S0140-6736(20)30154-9.

7. Huang C, Wang Y, Li X, Ren L, Zhao J, Hu Y, et al. Clinical features ofpatients infected with 2019 novel coronavirus in Wuhan, China. Lancet2020;395(10223):497-506, http://dx.doi.org/10.1016/S0140- 
6736(20)30183-5.

8. Chen T, Wu D, Chen H, Yan W, Yang D, Chen G, et al. Clinical characteristics of 113 deceased patients with coronavirus disease 2019: retrospective study. Br Med J 2020:368, http://dx.doi.org/10.1136/bmj.m1091.

9. Arentz M, Yim E, Klaff L, Lokhandwala S, Riedo F, Chong M, et al. Characteristics and outcomes of 21 critically III patients with COVID-19 in Washington State.J Am Med Assoc 2020, http://dx.doi.org/10.1001/jama.2020.4326.

10. World Health Organization. Coronavirus Disease (COVID-19) TechnicalGuidance: Laboratory Testing for 2019-nCoV in Humans; 2020 https://www.who.int/emergencies/diseases/novel-coronavirus2019/technical-guidance/laboratory-guidance.

11. Guan W, Ni Z, Hu Y, Liang W, Ou C, He J, et al. Clinical characteristics of Corona-virus Disease 2019 in China. New Engl J Med 2020, http://dx.doi.org/10.1056/NEJMoa2002032.

12. Goyal P, Choi J, Pinheiro L, Schenck E, Chen R, Jabri A, et al. Clinical characteristicsof Covid-19 in New York city. New Engl J Med 2020, http://dx.doi.org/10.1056/NEJMc2010419.

13. Zhou F, Yu T, Du R, Fan G, Liu Y, Liu Z, et al. Clinical course and risk factorsfor mortality of adult inpatients with COVID-19 in Wuhan, China: a retro-spective cohort study. Lancet 2020;395(10229):1054-62, http://dx.doi.org/10.1016/S0140-6736(20)30566-3.

14. M. Alsofayan et al., Journal of Infection and Public Health 13 (2020) 920-925

15. Arentz M, YimE, Klaff L, et al. Characteristics and outcomes of 21 critically ill patients with COVID-19 inWashington State. JAMA. 2020. doi:10.1001/jama.2020.4326

16. M. Samrah, et al., COVID-19 outbreak in Jordan: Epidemiological features, clinical characteristics, and laboratory findings, Annals of Medicine and Surgery 57 (2020) 103-108

17. Wang, B. Hu, C. Hu, et al., Clinical characteristics of 138 hospitalized patients with 2019 novel coronavirus-infected pneumonia in Wuhan, China, J. Am. Med. Assoc. (2020) published online Feb 7.

18. Huang, Y. Wang, X. Li, et al., Clinical features of patients infected with 2019 novel coronavirus in Wuhan, China, Lancet 395 (2020) 497-506.

19. Chen, M. Zhou, X. Dong, et al., Epidemiological and clinical characteristics of 99 cases of 2019 novel coronavirus pneumonia in Wuhan, China: a descriptive study, Lancet 395 (2020) 507-513.

20. F. Chan, S. Yuan, K.H. Kok, et al., A familial cluster of pneumonia associated with the 2019 novel coronavirus indicating person-to-person transmission: a study of a family cluster, Lancet 395 (2020) 514-523.

21. Young, S. Ong, S. Kalimuddin, et al., Epidemiologic features and clinical course of patients infected with SARS-CoV-2 in Singapore, J. Am. Med. Assoc. (2020 Mar3), https://doi.org/10.1001/jama.2020.3204.

\section{Tables}

Table (1): Patient information and demographic of COVID Patients $(n=336)$ 


\section{Gender}

Male

Female

\section{Nationality}

National (Emirati)

Non-National

\section{Age (years)}

$18-29$

$30-49$

$50-60$

Min. - Max.

$19-89$

Mean \pm SD.

$45.1 \pm$ 12.6

Median(IQR) $44(36-$ 54.5)

\section{Patient weight (kg)}

Min. - Max. $44.6-$ 133

Mean \pm SD.

$76.6 \pm$ 14.7

Median(IQR) $75(66.7$

$-85)$

\section{Patient risk factors}

Age $\geq 60$ 


\begin{tabular}{ll} 
Cardiovascular disease & $27(8 \%)$ \\
\hline Morbid obesity $(\mathrm{BMI}>40)$ & $3(0.9 \%)$ \\
\hline DM & $84(25 \%)$ \\
\hline Hypertension & 77 \\
\hline $\begin{array}{ll}\text { Immunocompromised: Active malignancy on immunomodulatory/ immunosuppressant } \\
\text { drugs Transplant HIV low CD4 count <200) }\end{array}$ & $(22.9 \%)$ \\
\hline Chronic liver disease & $(3.3 \%)$ \\
\hline Chronic kidney disease (eGFR<60 mL/min/1.73m2 or ESRD on HD) & $5(1.5 \%)$ \\
\hline Pregnancy $(\mathrm{n}=54)$ & 24 \\
\hline
\end{tabular}

Table (2): Demographic variables of COVID-19 cases in SKMC according to presence of clinical symptoms. $(n=336)$

\begin{tabular}{|c|c|c|c|c|c|}
\hline & \multicolumn{3}{|c|}{ Care related data [Patient level] } & \multirow[t]{2}{*}{ Test of Sig. } & \multirow[t]{2}{*}{$\mathbf{p}$} \\
\hline & $\begin{array}{l}\text { Level A } \\
(n=107)\end{array}$ & $\begin{array}{l}\text { Level B } \\
(n=215)\end{array}$ & $\begin{array}{l}\text { Level C } \\
(n=14)\end{array}$ & & \\
\hline \multicolumn{6}{|l|}{ Gender } \\
\hline Male & 75(70.1\%) & $194(90.2 \%)$ & $13(92.9 \%)$ & \multirow{2}{*}{$\begin{array}{l}c^{2}= \\
22.346^{*}\end{array}$} & \multirow[t]{2}{*}{$<0.001^{*}$} \\
\hline Female & $32(29.9 \%)$ & $21(9.8 \%)$ & $1(7.1 \%)$ & & \\
\hline Sig. bet. grps & \multicolumn{5}{|c|}{$\mathrm{p}_{1}<0.001^{*}, \mathrm{p}_{2}=0.109, \mathrm{p}_{3}=1.000$} \\
\hline \multicolumn{6}{|l|}{ Age (years) } \\
\hline $18-29$ & $16(15 \%)$ & $15(7 \%)$ & $0(0 \%)$ & \multirow{4}{*}{$\begin{array}{l}c^{2}= \\
16.715^{*}\end{array}$} & \multirow{4}{*}{$\begin{array}{l}{ }^{M C} p= \\
0.006^{*}\end{array}$} \\
\hline $30-49$ & $56(52.3 \%)$ & $124(57.6 \%)$ & $6(42.9 \%)$ & & \\
\hline $50-60$ & $17(15.9 \%)$ & $58(27 \%)$ & $5(35.7 \%)$ & & \\
\hline$>60$ & $18(16.8 \%)$ & $18(8.4 \%)$ & $3(21.4 \%)$ & & \\
\hline Mean \pm SD & $44 \pm 14.8$ & $45.1 \pm 11.2$ & $52.4 \pm 12.6$ & \multirow[t]{2}{*}{$H=6.328^{*}$} & \multirow[t]{2}{*}{$0.042^{*}$} \\
\hline Median (Min. - Max.) & $41(19-89)$ & $44(20-72)$ & $50.5(35-85)$ & & \\
\hline
\end{tabular}

\section{$c^{2}$ : Chi square test}

MC: Monte Carlo

$\mathrm{H}$ : $\mathrm{H}$ for Kruskal Wallis test 
$\mathrm{p}_{1}: \mathrm{p}$ value for comparing between Level $\mathbf{A}$ and Level $\mathbf{B}$

$\mathrm{p}_{2}: \mathrm{p}$ value for comparing between Level $\mathbf{A}$ and Level $\mathrm{C}$

$\mathrm{p}_{3}: \mathrm{p}$ value for comparing between Level $\mathrm{B}$ and Level $\mathrm{C}$

*: Statistically significant at $p \leq 0.05$

Level A: [The patient was Asymptomatic OR mild symptoms with radiological evidence of pneumonia (Mild)]

Level B: [The patient was Asymptomatic with radiological evidence of pneumonia OR mild URTI with risk factors (Moderate)]

Level C: [The patient was critically ill and admitted to ICU]

Table (3): Distribution of the Patients according to symptoms and vital signs $(n=336)$ 


\begin{tabular}{|c|c|}
\hline & No. (\%) \\
\hline \multicolumn{2}{|l|}{ Symptoms } \\
\hline No symptoms & $36(10.7 \%)$ \\
\hline Mild & $143(42.6 \%)$ \\
\hline Fever & $182(54.2 \%)$ \\
\hline Cough & $236(70.2 \%)$ \\
\hline Sore throat & $85(25.3 \%)$ \\
\hline Headache & $87(25.9 \%)$ \\
\hline Diarrhea & $56(16.7 \%)$ \\
\hline Moderate/sever & $157(46.7 \%)$ \\
\hline Shortness of breath & $146(43.5 \%)$ \\
\hline Chest Pain & $49(14.6 \%)$ \\
\hline \multicolumn{2}{|c|}{ Result of QTc on an ECG } \\
\hline$<430$ & $282(85.5 \%)$ \\
\hline $430-450$ & $33(10 \%)$ \\
\hline$>450$ & $15(4.5 \%)$ \\
\hline \multicolumn{2}{|l|}{ D-dimer result } \\
\hline$<1 \mathrm{mcg} / \mathrm{mL}$ & $166(74.1 \%)$ \\
\hline$>1 \mathrm{mcg} / \mathrm{mL}$ & $58(25.9 \%)$ \\
\hline \multicolumn{2}{|l|}{ Length of stay (days) } \\
\hline Min. - Max. & $1-32$ \\
\hline Mean \pm SD & $5 \pm 4.8$ \\
\hline Median(IQR) & $3(2-6)$ \\
\hline \multicolumn{2}{|c|}{ Length of stay (days) [ICU/HDU] } \\
\hline Min. - Max. & $1-21$ \\
\hline Mean \pm SD. & $6.3 \pm 5.8$ \\
\hline Median(IQR) & $4(1-9)$ \\
\hline \multicolumn{2}{|c|}{ What type of oxygen therapy? } \\
\hline Aerosol mask & $1(0.3 \%)$ \\
\hline
\end{tabular}




\begin{tabular}{|ll|}
\hline Intubation and invasive mechanical ventilation (IMV) & $5(1.5 \%)$ \\
\hline Nonil cannula & $75(22.3 \%)$ \\
\hline Non-Rebreathe masks (High Flow) & $6(1.8 \%)$ \\
\hline Oxygen mask & $1(0.3 \%)$ \\
\hline
\end{tabular}

Table (4): Risk Factors \& symptoms according to age group $(n=336)$

\begin{tabular}{|c|c|c|c|c|}
\hline & \multicolumn{4}{|l|}{ Age (years) } \\
\hline & $\begin{array}{l}18-29 \\
(n=31)\end{array}$ & $\begin{array}{l}30-49 \\
(n=186)\end{array}$ & $\begin{array}{l}50-60 \\
(n=80)\end{array}$ & $\begin{array}{l}>60 \\
(n=39)\end{array}$ \\
\hline \multicolumn{5}{|l|}{ Number of risk factors } \\
\hline No risk factor & 26(83.9\%) & $124(66.7 \%)$ & $19(23.8 \%)$ & $0(0 \%)$ \\
\hline 1 & $5(16.1 \%)$ & $45(24.2 \%)$ & $28(35 \%)$ & $8(20.5 \%)$ \\
\hline 2 & $0(0 \%)$ & $14(7.5 \%)$ & $20(25 \%)$ & $16(41 \%)$ \\
\hline 3 & $0(0 \%)$ & $2(1.1 \%)$ & $10(12.5 \%)$ & $7(17.9 \%)$ \\
\hline 4 & $0(0 \%)$ & $1(0.5 \%)$ & $3(3.7 \%)$ & $5(12.8 \%)$ \\
\hline 5 & $0(0 \%)$ & $0(0 \%)$ & $0(0 \%)$ & $2(5.2 \%)$ \\
\hline 6 & $0(0 \%)$ & $0(0 \%)$ & $0(0 \%)$ & $1(2.6 \%)$ \\
\hline \multicolumn{5}{|l|}{ Number of symptoms } \\
\hline No symptoms & $5(16.1 \%)$ & $15(8.1 \%)$ & $9(11.3 \%)$ & $7(17.9 \%)$ \\
\hline 1 & $10(32.3 \%)$ & $36(19.4 \%)$ & $14(17.5 \%)$ & 7(17.9\%) \\
\hline 2 & $5(16.1 \%)$ & $41(22 \%)$ & $16(20 \%)$ & $10(25.6 \%)$ \\
\hline 3 & $6(19.4 \%)$ & $47(25.3 \%)$ & $16(20 \%)$ & $8(20.5 \%)$ \\
\hline 4 & $1(3.2 \%)$ & $20(10.8 \%)$ & $14(17.5 \%)$ & $4(10.3 \%)$ \\
\hline 5 & $3(9.7 \%)$ & $18(9.6 \%)$ & $7(8.7 \%)$ & $2(5.2 \%)$ \\
\hline 6 & $1(3.2 \%)$ & $8(4.3 \%)$ & $2(2.5 \%)$ & $1(2.6 \%)$ \\
\hline 7 & $0(0 \%)$ & $1(0.5 \%)$ & $2(2.5 \%)$ & $0(0 \%)$ \\
\hline Patient with mild symptoms & $15(48.4 \%)$ & $85(45.7 \%)$ & $28(35 \%)$ & $15(38.5 \%)$ \\
\hline Patient with moderate/sever symptoms & $11(35.5 \%)$ & $86(46.2 \%)$ & $43(53.7 \%)$ & $17(43.6 \%)$ \\
\hline
\end{tabular}


Table (5): Outcomes for Patients Discharged Alive, Dead and readmission 


\begin{tabular}{|c|c|c|c|}
\hline & \multicolumn{2}{|c|}{ Patient discharge status } & \multirow{2}{*}{$\begin{array}{l}\text { Patient } \\
\text { readmission } \\
(n=16)\end{array}$} \\
\hline & $\begin{array}{l}\text { Alive } \\
(n=324)\end{array}$ & $\begin{array}{l}\text { Deceased } \\
(n=12)\end{array}$ & \\
\hline \multicolumn{4}{|l|}{ Gender } \\
\hline Male & $272(84 \%)$ & $10(83.3 \%)$ & $10(62.5 \%)$ \\
\hline Female & $52(16 \%)$ & $2(16.7 \%)$ & $6(37.5 \%)$ \\
\hline \multicolumn{4}{|l|}{ Nationality } \\
\hline National (Emirati) & $20(6.2 \%)$ & $1(8.3 \%)$ & $1(6.3 \%)$ \\
\hline Non-National & $304(93.8 \%)$ & $11(91.7 \%)$ & 15(93.7\%) \\
\hline \multicolumn{4}{|l|}{ Age (years) } \\
\hline $18-29$ & $31(9.6 \%)$ & $0(0 \%)$ & $1(6.3 \%)$ \\
\hline $30-49$ & $180(55.6 \%)$ & $6(50 \%)$ & $7(43.7 \%)$ \\
\hline $50-60$ & $78(24.1 \%)$ & $2(16.7 \%)$ & $4(25 \%)$ \\
\hline$>60$ & $35(10.7 \%)$ & $4(33.3 \%)$ & $4(25 \%)$ \\
\hline \multicolumn{4}{|l|}{ Patient risk factors } \\
\hline Age $\geq 60$ & $42(13 \%)$ & $3(25 \%)$ & $4(25 \%)$ \\
\hline Chronic lung disease including asthma or COPD & $16(4.9 \%)$ & $1(8.3 \%)$ & $1(6.3 \%)$ \\
\hline Cardiovascular disease & $27(8.3 \%)$ & $0(0 \%)$ & $1(6.3 \%)$ \\
\hline Morbid obesity $(\mathrm{BMI}>40)$ & $1(0.3 \%)$ & $2(16.7 \%)$ & $0(0 \%)$ \\
\hline DM & $77(23.8 \%)$ & $7(58.3 \%)$ & $6(37.5 \%)$ \\
\hline Hypertension & $75(23.1 \%)$ & $2(16.7 \%)$ & $2(12.5 \%)$ \\
\hline $\begin{array}{l}\text { Immunocompromised: Active malignancy on } \\
\text { immunomodulatory/ immunosuppressant drugs } \\
\text { Transplant HIV low CD4 count <200) }\end{array}$ & $10(3.1 \%)$ & $1(8.3 \%)$ & $2(12.5 \%)$ \\
\hline Chronic liver disease & $5(1.5 \%)$ & $0(0 \%)$ & $0(0 \%)$ \\
\hline $\begin{array}{l}\text { Chronic kidney disease (eGFR }<60 \mathrm{~mL} / \mathrm{min} / 1.73 \mathrm{~m} 2 \text { or } \\
\text { ESRD on HD) }\end{array}$ & $23(7.1 \%)$ & $1(8.3 \%)$ & $3(18.8 \%)$ \\
\hline Pregnancy & $2(0.6 \%)$ & $0(0 \%)$ & $0(0 \%)$ \\
\hline \multicolumn{4}{|l|}{ Number of risk factors } \\
\hline No risk factor & $167(51.5 \%)$ & $2(16.7 \%)$ & $5(31.3 \%)$ \\
\hline 1 & $81(25 \%)$ & $5(41.7 \%)$ & $6(37.4 \%)$ \\
\hline
\end{tabular}




\begin{tabular}{|c|c|c|c|}
\hline 2 & $46(14.2 \%)$ & $4(33.3 \%)$ & $3(18.7 \%)$ \\
\hline 3 & $19(5.9 \%)$ & $0(0 \%)$ & $1(6.3 \%)$ \\
\hline 4 & $8(2.5 \%)$ & $1(8.3 \%)$ & $1(6.3 \%)$ \\
\hline 5 & $2(0.6 \%)$ & $0(0 \%)$ & $0(0 \%)$ \\
\hline 6 & $1(0.3 \%)$ & $0(0 \%)$ & $0(0 \%)$ \\
\hline Median(IQR) & $1(1-2)$ & $1.5(1-2)$ & $1(1-2)$ \\
\hline D-dimer result & $(n=214)$ & $(n=10)$ & $(n=10)$ \\
\hline$<1 \mathrm{mcg} / \mathrm{mL}$ & $163(76.2 \%)$ & $3(30 \%)$ & $7(70 \%)$ \\
\hline$>1 \mathrm{mcg} / \mathrm{mL}$ & $51(23.8 \%)$ & $7(70 \%)$ & $3(30 \%)$ \\
\hline \multicolumn{4}{|l|}{ Length of stay (days) } \\
\hline Mean \pm SD & $4.8 \pm 4.6$ & $10.2 \pm 7.8$ & $4.3 \pm 3.9$ \\
\hline Median (Min. - Max.) & $3(1-32)$ & $9(2-23)$ & $3(1-17)$ \\
\hline \multicolumn{4}{|c|}{ Length of stay (days) [ICU/HDU] } \\
\hline Mean \pm SD & $5.7 \pm 5.4$ & $8.7 \pm 7.2$ & $2.5 \pm 1.7$ \\
\hline Median (Min. - Max.) & $3(1-21)$ & $9(1-20)$ & $2(1-5)$ \\
\hline \multicolumn{4}{|l|}{ Number of symptoms } \\
\hline No symptoms & $35(10.8 \%)$ & $1(8.4 \%)$ & $2(12.5 \%)$ \\
\hline 1 & $67(20.7 \%)$ & $0(0 \%)$ & $3(18.7 \%)$ \\
\hline 2 & $70(21.6 \%)$ & $2(16.7 \%)$ & $5(31.3 \%)$ \\
\hline 3 & $74(22.8 \%)$ & $3(25 \%)$ & $0(0 \%)$ \\
\hline 4 & $35(10.8 \%)$ & $4(33.3 \%)$ & $5(31.3 \%)$ \\
\hline 5 & $29(9 \%)$ & $1(8.3 \%)$ & $0(0 \%)$ \\
\hline 6 & $11(3.4 \%)$ & $1(8.3 \%)$ & $1(6.2 \%)$ \\
\hline 7 & $3(0.9 \%)$ & $0(0 \%)$ & $0(0 \%)$ \\
\hline Median(IQR) & $3(0-1)$ & $4(1-2)$ & $2(2-4)$ \\
\hline
\end{tabular}

Table (6): Clinical Measures and Outcomes for Patients Discharged Alive and Dead 


\begin{tabular}{|c|c|c|c|c|c|}
\hline & & Age (years & & & \\
\hline & & $18-29$ & $30-49$ & $50-60$ & $>60$ \\
\hline Discharged & Gender & $(n=31)$ & $(n=180)$ & $(n=78)$ & $(n=35)$ \\
\hline & Male & $27(87.1 \%)$ & $151(83.9 \%)$ & $69(88.5 \%)$ & $25(71.4 \%)$ \\
\hline & Female & $4(12.9 \%)$ & $29(16.1 \%)$ & $9(11.5 \%)$ & $10(28.6 \%)$ \\
\hline & Length of stay (days) & $(n=31)$ & $(n=180)$ & $(n=78)$ & $(n=35)$ \\
\hline & Mean \pm SD. & $3.3 \pm 3.4$ & $5 \pm 5$ & $4.8 \pm 4.4$ & $5.2 \pm 3.4$ \\
\hline & Median (Min. - Max.) & $2(1-13)$ & $3(1-32)$ & $3(1-20)$ & $4(1-14)$ \\
\hline & $\begin{array}{l}\text { Length of stay [ICU/HDU] } \\
\text { (days) }\end{array}$ & $(n=8)$ & $(n=29)$ & $(n=14)$ & $(n=2)$ \\
\hline & Mean \pm SD. & $3.8 \pm 3.2$ & $5.8 \pm 5.9$ & $6.6 \pm 5.7$ & $6 \pm 4.2$ \\
\hline & Median (Min. - Max.) & $2.5(1-9)$ & $3(1-21)$ & $\begin{array}{l}4.5(1- \\
17)\end{array}$ & $6(3-9)$ \\
\hline & Result of QTC on an ECG & $(n=30)$ & $(n=176)$ & $(n=78)$ & $(n=35)$ \\
\hline & $<430$ & $29(96.7 \%)$ & $155(88.1 \%)$ & $63(80.8 \%)$ & $26(74.3 \%)$ \\
\hline & $430-450$ & $1(3.3 \%)$ & $16(9.1 \%)$ & $10(12.8 \%)$ & $5(14.3 \%)$ \\
\hline & $>450$ & $0(0 \%)$ & $5(2.8 \%)$ & $5(6.4 \%)$ & $4(11.4 \%)$ \\
\hline & Mean \pm SD. & $\begin{array}{l}391.6 \pm \\
20.3\end{array}$ & $401 \pm 25.8$ & $\begin{array}{l}408 \pm \\
23.7\end{array}$ & $\begin{array}{l}414.7 \pm \\
32.1\end{array}$ \\
\hline & Median (Min. - Max.) & $\begin{array}{l}389.5(363 \\
-442)\end{array}$ & $\begin{array}{l}397(357- \\
574)\end{array}$ & $\begin{array}{l}406.5(361 \\
-467)\end{array}$ & $\begin{array}{l}409(372- \\
505)\end{array}$ \\
\hline & D-dimer result & $(n=14)$ & $(n=118)$ & $(n=54)$ & $(n=28)$ \\
\hline & $<1 \mathrm{mcg} / \mathrm{mL}$ & $13(92.9 \%)$ & $86(72.9 \%)$ & $42(77.8 \%)$ & $22(78.6 \%)$ \\
\hline & $>1 \mathrm{mcg} / \mathrm{mL}$ & $1(7.1 \%)$ & $32(27.1 \%)$ & $12(22.2 \%)$ & $6(21.4 \%)$ \\
\hline & What type of oxygen therapy? & $(n=5)$ & $(n=53)$ & $(n=17)$ & $(n=5)$ \\
\hline & Aerosol mask & $1(20 \%)$ & $0(0 \%)$ & $0(0 \%)$ & $0(0 \%)$ \\
\hline & $\begin{array}{l}\text { Intubation and invasive } \\
\text { mechanical ventilation (IMV) }\end{array}$ & $0(0 \%)$ & $1(1.9 \%)$ & $0(0 \%)$ & $0(0 \%)$ \\
\hline & Nasal cannula & $4(80 \%)$ & $46(86.8 \%)$ & $15(88.2 \%)$ & $5(100 \%)$ \\
\hline & $\begin{array}{l}\text { Noninvasive ventilation } \\
\text { (BIPAP,CPAP) }\end{array}$ & $0(0 \%)$ & $3(5.7 \%)$ & $0(0 \%)$ & $0(0 \%)$ \\
\hline & $\begin{array}{l}\text { Non-Rebreathe masks (High } \\
\text { Flow) }\end{array}$ & $0(0 \%)$ & $0(0 \%)$ & $1(5.9 \%)$ & $0(0 \%)$ \\
\hline
\end{tabular}




\begin{tabular}{|c|c|c|c|c|c|}
\hline & Oxygen mask & $0(0 \%)$ & $3(5.7 \%)$ & $1(5.9 \%)$ & $0(0 \%)$ \\
\hline \multirow[t]{24}{*}{ Deceased } & Gender & $(n=0)$ & $(n=6)$ & $(n=2)$ & $(n=4)$ \\
\hline & Male & - & $5(83.3 \%)$ & $2(100 \%)$ & $3(75 \%)$ \\
\hline & Female & - & $1(16.7 \%)$ & $0(0 \%)$ & $1(25 \%)$ \\
\hline & Length of stay (days) & $(n=0)$ & $(n=6)$ & $(n=2)$ & $(n=4)$ \\
\hline & Mean \pm SD. & - & $16 \pm 5.9$ & $7.5 \pm 7.8$ & $2.8 \pm 0.5$ \\
\hline & Median (Min. - Max.) & - & $17(8-23)$ & $\begin{array}{l}7.5(2- \\
13)\end{array}$ & $3(2-3)$ \\
\hline & $\begin{array}{l}\text { Length of stay [ICU/HDU] } \\
\text { (days) }\end{array}$ & $(n=0)$ & $(n=6)$ & $(n=2)$ & $(n=4)$ \\
\hline & Mean \pm SD. & - & $14 \pm 5.3$ & $6.5 \pm 7.8$ & $1.8 \pm 1$ \\
\hline & Median (Min. - Max.) & - & $\begin{array}{l}13.5(8- \\
20)\end{array}$ & $\begin{array}{l}6.5(1- \\
12)\end{array}$ & $1.5(1-3)$ \\
\hline & Result of QTc on an ECG & $(n=0)$ & $(n=5)$ & $(n=2)$ & $(n=4)$ \\
\hline & $<430$ & - & $5(100 \%)$ & $1(50 \%)$ & $3(75 \%)$ \\
\hline & $430-450$ & - & $0(0 \%)$ & $1(50 \%)$ & $0(0 \%)$ \\
\hline & $>450$ & - & $0(0 \%)$ & $0(0 \%)$ & $1(25 \%)$ \\
\hline & Mean \pm SD. & - & $\begin{array}{l}374.8 \pm \\
30.6\end{array}$ & $\begin{array}{l}417 \pm \\
43.8\end{array}$ & $\begin{array}{l}415.8 \pm \\
49.8\end{array}$ \\
\hline & Median (Min. - Max.) & - & $\begin{array}{l}366(348- \\
426)\end{array}$ & $\begin{array}{l}417(386 \\
-448)\end{array}$ & $\begin{array}{l}414.5(356 \\
-478)\end{array}$ \\
\hline & D-dimer result & $(n=0)$ & $(n=5)$ & $(n=1)$ & $(n=4)$ \\
\hline & $<1 \mathrm{mcg} / \mathrm{mL}$ & - & $3(60 \%)$ & $0(0 \%)$ & $0(0 \%)$ \\
\hline & $>1 \mathrm{mcg} / \mathrm{mL}$ & - & $2(40 \%)$ & $1(100 \%)$ & $4(100 \%)$ \\
\hline & What type of oxygen therapy? & $(n=0)$ & $(n=6)$ & $(n=2)$ & $(n=4)$ \\
\hline & Aerosol mask & - & $0(0 \%)$ & $0(0 \%)$ & $0(0 \%)$ \\
\hline & $\begin{array}{l}\text { Intubation and invasive } \\
\text { mechanical ventilation (IMV) }\end{array}$ & - & $3(50 \%)$ & $1(50 \%)$ & $0(0 \%)$ \\
\hline & Nasal cannula & - & $2(33.3 \%)$ & $0(0 \%)$ & $3(75 \%)$ \\
\hline & $\begin{array}{l}\text { Noninvasive ventilation } \\
\text { (BIPAP,CPAP) }\end{array}$ & - & $1(16.7 \%)$ & $1(50 \%)$ & $1(25 \%)$ \\
\hline & $\begin{array}{l}\text { Non-Rebreathe masks (High } \\
\text { Flow) }\end{array}$ & - & $0(0 \%)$ & $0(0 \%)$ & $0(0 \%)$ \\
\hline
\end{tabular}


Table (7): Patient Discharge Status \& Readmission According to Age

\begin{tabular}{|c|c|c|c|c|}
\hline \multirow[t]{2}{*}{ Outcomes } & \multicolumn{4}{|l|}{ Age (years) } \\
\hline & $\begin{array}{l}18-29 \\
(n=31)\end{array}$ & $\begin{array}{l}30-49 \\
(n=186)\end{array}$ & $\begin{array}{l}50-60 \\
(n=80)\end{array}$ & $\begin{array}{l}>60 \\
(n=39)\end{array}$ \\
\hline \multicolumn{5}{|c|}{ Patient discharge status } \\
\hline Health care facility & $4(12.9 \%)$ & $17(9.2 \%)$ & $7(8.8 \%)$ & $0(0 \%)$ \\
\hline Quarantine & $27(87.1 \%)$ & $163(87.6 \%)$ & $71(88.7 \%)$ & $35(89.7 \%)$ \\
\hline Deceased & $0(0 \%)$ & $6(3.2 \%)$ & $2(2.5 \%)$ & $4(10.3 \%)$ \\
\hline \multicolumn{5}{|l|}{ Patient readmission } \\
\hline No & $30(96.8 \%)$ & $179(96.2 \%)$ & $76(95 \%)$ & $35(89.7 \%)$ \\
\hline Yes & $1(3.2 \%)$ & $7(3.8 \%)$ & $4(5 \%)$ & $4(10.3 \%)$ \\
\hline
\end{tabular}

